\title{
米沢盆地の大谷 地*
}

\section{吉田義 信**}

1. 緒言 大谷地は米沢盈地の北東隅に位置し，赤湯町と屋代村とに亘 り約 1000 町齿を占めている. 5 万分の 1 赤湯図幅を見ると大部分「沿田」 と交つて未り, 大谷地西辺の吉野川, 南辺の屋代川のバックマーシュ ${ }^{(1) か ゙ ~}$ 干拓された ${ }^{(2)}$ よらに思われるが，干拓の計画は旧藩時代以来 5 回あつたけ れぞも実行されなかつた(3). 大谷地の急速な水田化は奥羽線が赤湯女で通 じた明治 33 年以降のととで, それ以前は芦谷地であった。旧幕領の屋代村 に属する大谷地は寛文 4 年 (1664) 〜元祿 4 年 (1691) の間に於て地物の 見通の線を以て時沢，三条目，竹森（根岸大会），深沼の各旧村に分割さ れたが，深沼村と竹森村との境界はその争いの方め，寛政 8 年 (1796) 以 降従来の見通し線より 35 間深沼村に寄つたところにある(4). 芦仃りにつ らて各村は村落からの距離によつて 3 つ大割りし，更に各所を芦朾りす る権利をもつ戸数に応じて小割りし，毎年鐵引きで朾地を決定し，「野の 口明け」の日に一斎に刈取る割換制をとつてきたが明治初年に固定した ${ }^{(5)}$.

大谷地が米沢盈地の最後の開拓地域となったのは, 浮島状泥炭地で水田 化困離であること，慶長 4 年（1599）以来，大谷地の自然的排水路を締切 り大谷地に湛水するととによって此処から引水し屋代川南岸地域を灌溉し ている治部堰の水利権によって開拓が抑制されたとと，及び大谷地周辺農 村がかかる困難を押してまで马開墾しなければならぬ事情が稀薄であった ととによる(6). 然るに現在は高皇町北方の蛭沢に貯水量 219 万 $\mathrm{m}^{3}$ の溜池 完成し，てれによって高鼻町一带の用水補給及び大谷地の灌溉が行われ， 更に干拓による大谷地の土地改良事業が行われようとしている．果して大 谷地は排水によって直ちに良田となるであろらか。

2. 大谷地の地理的暴観 大谷地の田には谷地田と浮田との区別がある. 谷地田は大谷地周辺にあり, 泥宸地を長年耕作した結果それが圧縮され地 表面が空夕，下の水と混合して浮泥状となり年中湛水している水田である. 第 1 図は山形県耕地課で測量した 3,000 分の 1 地形図によったのである が，棚塚，松沢，日向，野手倉の各村落前の大谷地は附近一般の地面より も窪んだ状態が示されている.浮泥状の谷地田では田下䭾を便用すうとと

* 日本地理学会 1953 年度秋季学術大会講演要旨 地理学評諣 28 卷 2 号 (1955 年 2 月) 地理評. 26. 別冊 2 .

** 山形大学教育学部地理学教空. 


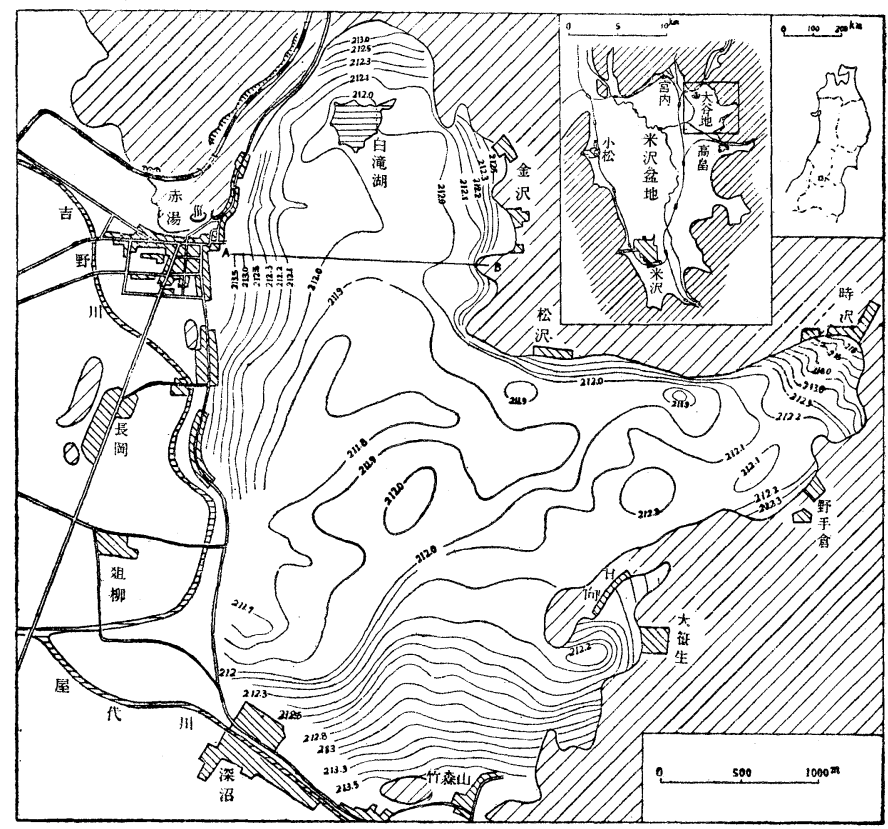

第1図大谷地 $\odot$ 地形

Contour map of the surfase of Ōyachi

がですず，田植え等の作業は腰を洺して行わなければならない。谷地田の 面積住約 700 町步に達するが米作は旱魅の年にかえつてよい結果を得る。

これに詨し浮田は面積約 250 町歩あり，新墾の田地で水の上に田が浮いて 打り，田面に水が載らず灌溉水は地下水状になつているので第 1 表に示す よらに温度低らため稲の成育悪く，旱魅に際しては表面団結し除草困難で 収獲量は少ない。浮田で泥炭の切れた所は「抜け田」と呼ばれ耕作に危険 である、浮田の耕起，堆肥撒布，田植え，稲の刚取り等の作業には「板か んじ」と称する⿴下䭾を用い，除草に際しては竹の丸太を渡しそれに乗 っておとなら。

蛭沢貯水池の水を日向に迴し長峯山をトンネルを以て通し灌水している が，浮田では容易に滲透し潤ら範囲が狭く，それが谷地田に湛水するので 同一大谷地内の田地でありながら用排水が相反し，水利統制は頗る困難で ある・大谷地は一時殆ど全部開田されたが芦生地に還元したととろもあり， 現在芦谷地の面積は約 70 町路である. 畦畔には勿論，田地の中にも芦占 
第 1 表 谷地田，浮田，畑の温度

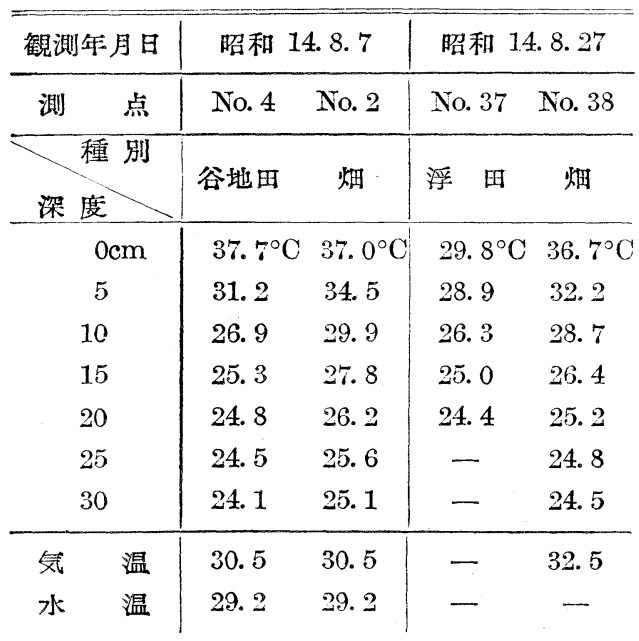

生えこの除去は容易でない。 畔けずりが大鎌で行われる のも大谷地の特色である. 大谷地内には白竜湖加らの 沼尻川 (治部堰) や時沢川 に連絡する灌溉排水雨用の らわゆる「頭無し水路」が 多数存し，肥料や稻を運搬 专る「谷地舟」の通路と８ なる。舟の通行のため太鼓 橋が各所にあり，板の片方 を止めた開閉式の簡单索橋 \&多い. 然し畦畔は水路で 切られているため，それを 伝つての步行は一般浪困

難である。

3. 浮島状泥炭地 大谷地が浮島状泥崖地であることは以下の諸事実に よって推察される.（1）未墾地や水田の畦畔を踏むと一帯がゆれる.（2） 白竜湖には浮島があり，明治 29 年の役場の地図の浮島は今は東岸に附着 している.（3）大谷地内の道路は盛土する. 赤湯・松沢間 $1500 \mathrm{~m} の$ 道路 には現在まで 70 年間に延 $10 \mathrm{~m}$ 盛土したが附近の田面より，やや高い程度 でこの画側は窪んで湖水状となり, その外側は衞起して水が乗らない。 （4）田地の形は短冊型で白竜湖東辺では5間に 12 間孙 3 間に 14 間の大き さが一般で，畦畔の幅は 1.5〜2.0間である。乙れは田地を浮か寸必要が あるからである。（う）浮田の泥炭が切れた部分を「拔け田」と呼び底無し 田である。（6）文畫に浮島状の泥炭地であることを記したのが散見される。 例えげ明和 9 年 (1772) 幕府の見分役が大谷地開発につを意見孛求めたと とに対于る深沼，根岸，竹森 3 筒村の返答の中に「右谷地之儀，全体草萱 根連り浮島之如牛故，少及切抜候而茂皆以水二御座候. 武三間有之竿突通 候而茂底土無之程之場所故……(7)」とある。また明和 2 年（1765）以来の 治部堰と右京堰その他との水論について安政 5 年 (1858) 幕府と米沢藩と の立合検分が行われた際の「谷地水一件大見分日記」に「新開之分八浮田 二而水湛無之」とある. 更に明治 12 年米沢旧藩士佐藤乾の開墾飞対し， 深沼村より県令及び部長に出した開墾反対の上申畫に「彼開茬ノ素志八白

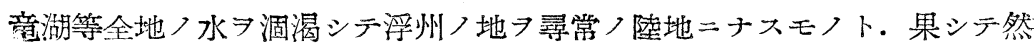


ラバ凹地トナルコト論フ俟タズ。夫レ浮地ノ如キ該地八箖雨数日二遭七， 洪水暴溢シテ頓二浮ム $习$ 得ス，一面湖水トナリテ地上数尺二及ブコト敢テ 珍ラシカラズ」とある.（7）白竜湖附近に於て筆者が昭和 15 年に $5 \mathrm{~m} の$ ボーリングステックを用いて泥宸層の厚さを調查(6)したが，泥孷層はステ ックを片手で刺し込める軟かさで，それを突を抜けると急に手応えがなく なり，ステックを抜くとをの穴からメタンガスと共に地表に水状の泥炭泥 が $っ 〜 7$ 秒間噴出し，その水は地表面下 $3 \sim 5 \mathrm{~cm}$ のととろで静止する.

(8). 昭和 6 年夏と昭和 27 年夏の山形県耕地課の地形測量資料によって高 度变化量の分布を示したのが第 2 図である. 白竜湖附近については昭和 6 年の資料がないので示

すととができないが， 図の大谷地の大部分は $60 \mathrm{~cm}$ 以上洸下乙, 内 部に於ては幹線水路に 沿い 80 90 cm の沈下 量を示している. 昭和 23 年制水門が完成し てから非灌激期間はで をるだけ排水する方針 をとっているので，泥 炭層の沈下を来したも のであろら。

\section{以上の諸事実により} 大谷地住笚飞排水不良

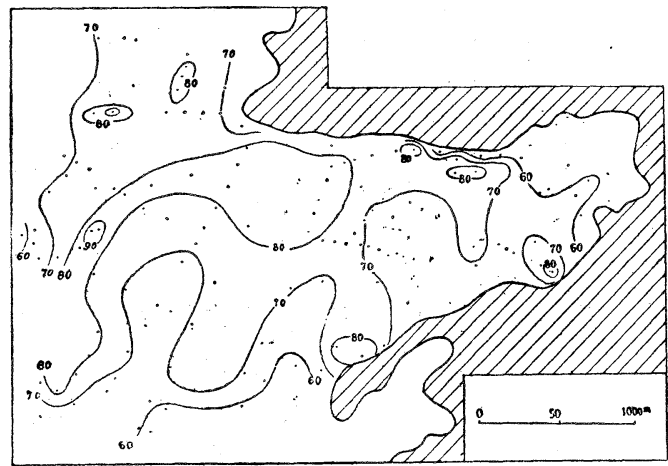

第 2 図 自昭和 6 年至昭和 27 年大谷地 表面の沈下量 $(\mathrm{cm})$ Amount of subsidence took place during 1931 1952 of the surface of Ōyachi (cm.)

の湿地ではなく，表面に浮島状泥炭をもつ湖沼であるととを確信するよう になった・たまたま大谷地干拓計画が具体化してをたので，泥炭層の厚さ を大谷地全域に亘って調査すると共に，その下の水の深さ，更に泥の厚さ を測定する必要があると考元，直径 2 分 5 厘の鉄棒に目盛を施し， $2 \mathrm{~m}$ 每 飞着脱でをるボーリングステックを考案した．尖端に突起部をつくり手応 えによって泥崖層突き抜けた深さ即ち泥宸層の厚さ，泥に達した深さ即 ち湖底深度，及び基盤に達し它深さが知られるよ5にし，昭和 28 年 8 月 白竜湖附近一蒂の地域について試夕をととろ，予想通りの性状をもつ土地

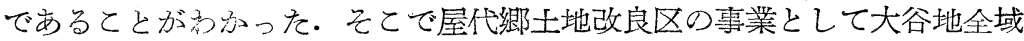
そついて調查し，筆者の調査と合せ 53 日，延 110 人で， 423 箇所のボー シングを行った。 
4. 泥炭層の厚さ「もくれ」とよばれ主として植物根からなる泥炭層 の厚さは第 3 図に見る如 $2.0 \mathrm{~m}$ 以下であるが，白竜湖を含久その南部一

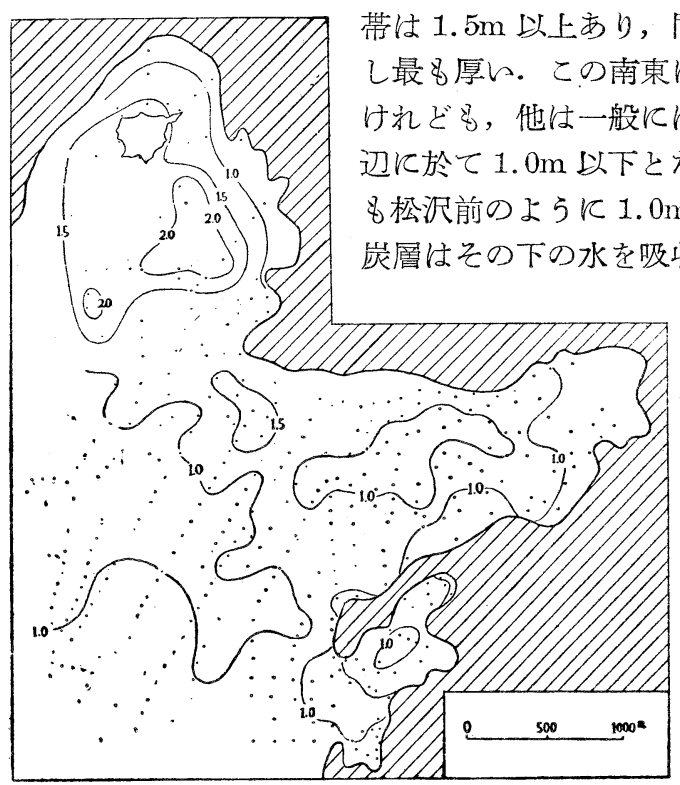

第 3 図泥炭層の厚さの分布 Distribution of the thickness of the peat layer 同湖の南東は $2.0 \mathrm{~m}$ を示. \& $1.5 \mathrm{~m}$ の場所がある は $1.0 \mathrm{~m}$ 前後で大谷地周 なる。然し大谷地内部に $\mathrm{m}$ 以下の場所がある.泥 して地表にはミズゴケ が繁茂し高位湿原を形 成し温度は低々. 昭和 14 年 8 月 3 日, 白竜 湖の表面水温 $29.8^{\circ} \mathrm{C}$, 水深 $1.5 \mathrm{~m}$ 飞於 $26.8^{\circ} \mathrm{C}$ の時, 寒暖計 の水銀球をガーゼ 15 枚で包夕てれをトタン の内筒に入れて密閉し 湖畔の泥崖の地表下 $10 \mathrm{~cm}$ に和き, 翌日乙 れを検したところ $14.9^{\circ} \mathrm{C}$ を測った. 海 抜 $212 \mathrm{~m}$ であるにも拘 わらず，サハラン，トキソウ，ツルコケ气モ，モウセンゴケ，ホッキョク スギ等の高山植物が生育し, 浮田の稲の生育不良の原因がこの点にあるも のと考元られる.

5. 湖盆形態 泥宸層が水の上に浮いているといつても, その中に水が 地下水状になつて含まれているから大谷地全域を一つの湖沼と考えてよい ので，第 4 図は地表面から泥までの梁さの分布を示した．正確に言えば湛 水状の谷地田では水面，浮田では地下水面を基準にして深さを測定しなけ ればなら学いが，手応えによる測定の誤差に比べれば問題にならない. 白 竜湖を含久南北 $1200 \mathrm{~m}$, 東西 $400 \mathrm{~m}$ に亘って $8 \mathrm{~m}$ 余の最深部あり殆ど平坦 で，との周りの $6 \sim 8 \mathrm{~m}$ は急，4〜 $6 \mathrm{~m}$ は緩で東岸に至り比較的急になつ ている. 松沢前に南北の幅 $500 \mathrm{~m}$ ，東西 $2500 \mathrm{~m}$ ，梁度 $4 \sim 5 \mathrm{~m}$ の場所があ り, との東に深度 $4 \mathrm{~m}$ 余の副湖盆がある. 大谷地南半は日向前に $4 \mathrm{~m}$ 余の 副湖盆ある外は $2 \sim 4 \mathrm{~m}$ の深度をるつ単調壱湖盈形態である. 白竜湖の水 


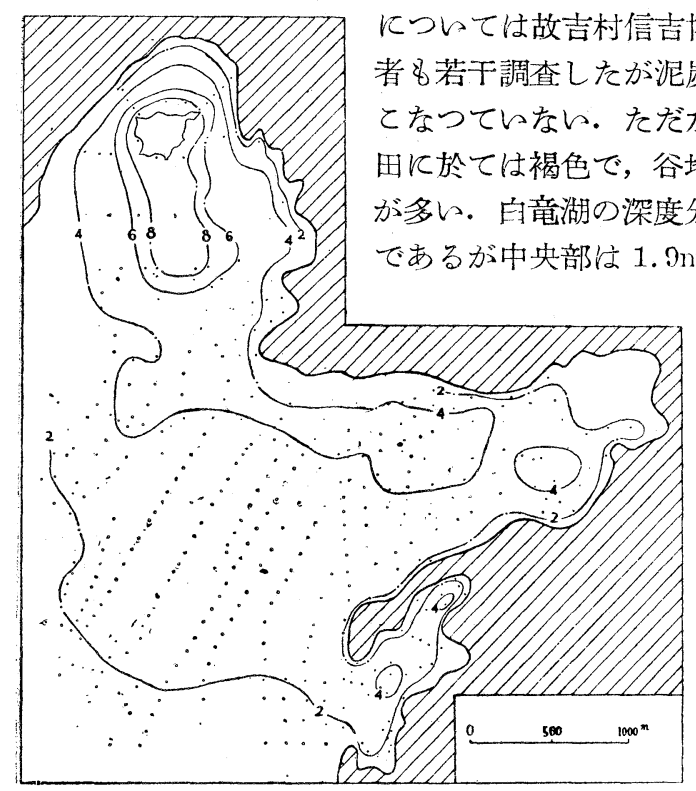

第 4 図 湖盆形態（地表より泥むでの 深さの分布)

Shape of the lake basin (mud surface) 大谷地生成の機巧は樑 泥ヶ池(9)等(10) と同様 と考えられ, 白竜湖附 近一带は水深大であつ たので水生植物の生育

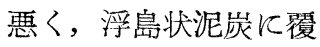
われるととから免れた \&ので, 水深 $1.9 \mathrm{~m}$ の 白竜湖の湖底住底 (11)である. 白竜湖と 同性質の小湖沿は大谷 地内の所々に存在市る.

6. 基盤の形態 ボ

ーリングステックが泥 考突き抜け，手店 えがあつてそれ以 上入らぬ深さを以 七基盤の深度と し, 海抜等高線孛 以て示したのが第 7 図である。基盤 の性質は不明であ らが，赤湯温泉や 屋代郎土地改良区 のコア・ボーリン グから推察すれば 砂礫尿で，小丘は 岩盤であろら，白 竜湖附近が最昌低

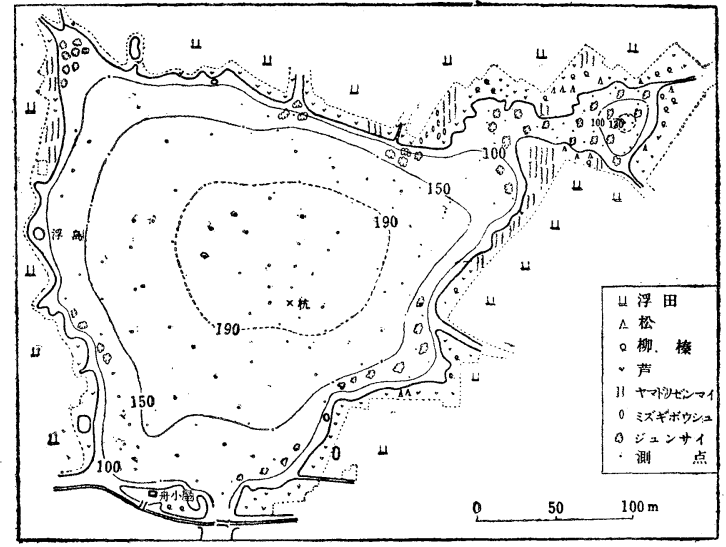

第5囟 白龍湖の深度扎上で湖宸の植物群灌 Depth of Lake Hakuryū 
く $198 \mathrm{~m}$ を示し，とこから約 $20 \mathrm{~km}$ 下流の長井町附近と略々同じ高度で， 地表面からの深度 $14 \mathrm{~m}$ の地域と一致する．202m 以下の地域は中央よりや

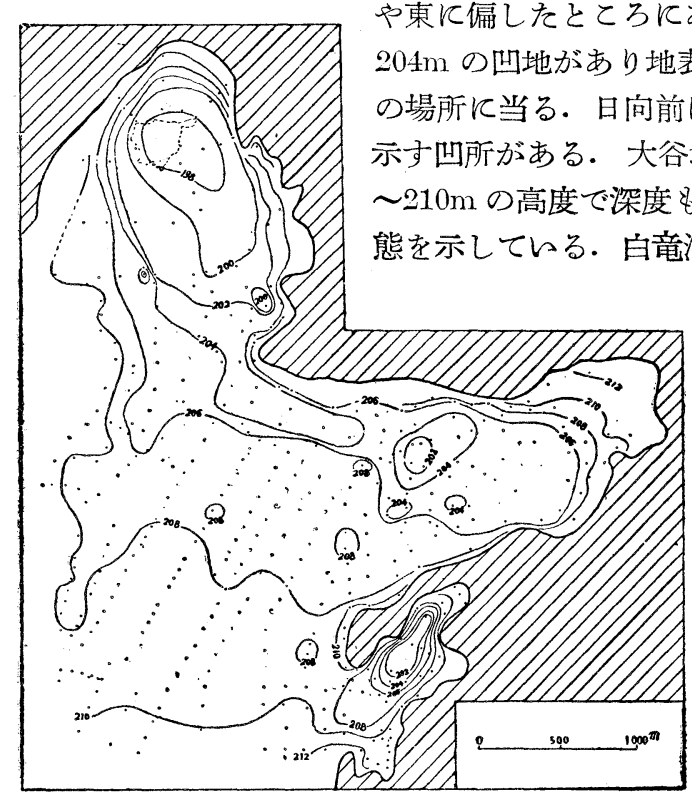

第 6 図 基盤の海拔等高線 Base of Oyachi shown by contour lines in altitude above sea level 深度 $4 \mathrm{~m}$ で附近より急 K $6 \mathrm{~m}$ 突起している 小丘の存在が慥めら充 た。この外に図に表現

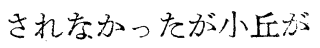
6 , 凹地が 8 発見され た. 基盤の形態を湖盆 形態と比較すると，そ れよりも凹凸著しく最 低部が東に偏している ことが異る点である. 去打基盤や湖盆の山所 とは無関係に沼尻川や 時沢川が流れていると とは注意しなければならない点で，干拓の際に利ける排水路の位置選定に 於て考慮しなければならないととであろら。

7. 泥の厚さ 第8図に示したよらに大体の傾向から言えば基盤等高線 四と類似し，泥は基盤深度大なる場所に厚く堆積している. 最も厚く堆積 しているところは, 白竜湖の南東の山麓に寄つたとてろにあって $8 \mathrm{~m}$ 余を 示し，基盤の最深部を埋積するよらに堆積したてとを示している。てれは 松沢前の $3 \sim 7 \mathrm{~m}$ ，日向前の $2 \sim 8 \mathrm{~m}$ の泥の深さをもつ地域についても同 様である.

8. 結語 以上記述した泥孷, 水, 泥及び基盤の相互関係を白竜湖南方 の赤湯より松沢に通ずる道路に沿 万延長 $1500 \mathrm{~m}$ の断面（第 1 図の A-B 線）で示したのが第 8 図である.基盤の深所は東に寄つたところにあつて $12 \mathrm{~m}$ を示し，泥もこの方面に厚く堆積して $6 \mathrm{~m}$ あり，このため湖底の深 い部分は中央部にあり $7.5 \mathrm{~m}$ 走している.かかる湖水に1.5〜2.0mの泥 


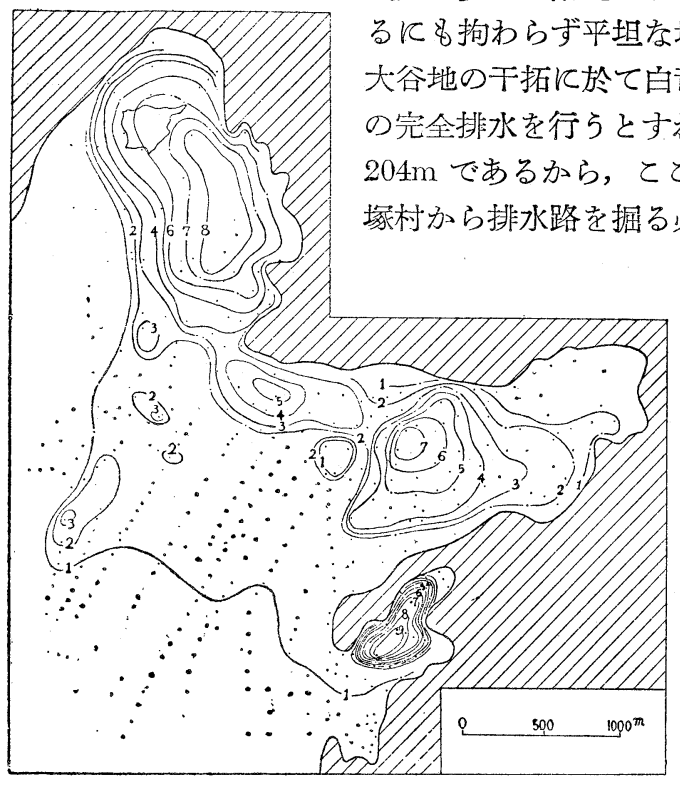

第7図泥の厚さの分布 Distribution of the thickness of mud

孷層が発達し附近より $6 \mathrm{~m}$ 女突起した小丘あ るに8拘わらず平坦な地表面を形成している。 大谷地の干拓に於て白竜湖附近の水深 $8 \mathrm{~m}$ まで の完全排水を行らとすれば湖底の海抜高度は ら，とこから約 $12 \mathrm{~km}$ 下流の大 要があり. 電力排水と すれば大谷地の貯溜水 2000 万 $\mathrm{m}^{3}$ 余の排水を しなければならず，と れは蛭沢貯水池の貯水 量の約10 倍に当る. 8 し水位を $4 \mathrm{~m}$ 低下させ るとすれば約 $9 \mathrm{~km}$ 下 流加ら排水路を掘るか， 電力排水とすれば同様 約 1600 万 $\mathrm{m}^{3}$ の排水を 行わ索ければならない。 後者の場合, $4 \mathrm{~m}$ 以上 の水深の部分は俵然と

して浮島状泥宸地とし て残るわけである。随 つて灌溉水源をもつ田。

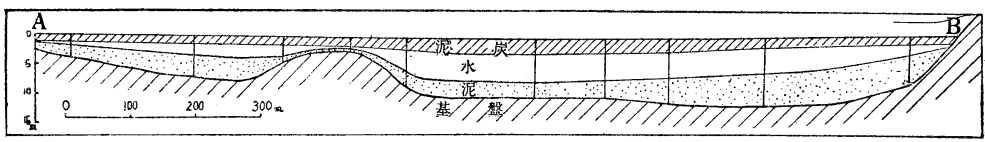

第 8 図大谷地の断面（場所は第1図のA-B間）

Cross section of Oyachi. From the surfaec to the bottom : layer of peat, water, mud and the base (as to the location of $\mathrm{A}-\mathrm{B}$, see Fig. 1)

地以外の灌溉については電力揚水によつて大谷地低所の水をその周辺に導 く循環方式をとるととが適当と考えられる。 また排水された大谷地につい ては充分客土をするか，泥宸を除く必要があろら。

(1954 年 9 月 9 日受理) 


\section{参考交献}

1. 東木竜七：地誌学 (1936) p. 152. 2. 酉水孜郎：日本の農業一一に経清 地理学的研究, 第 3 図 (1949). 3. 拙稿: 山形暻白竜湖附近の開拓之水利の問題. 東北地理，2. (1949). 4. 拙稿 : 谷地境論の一考察一米沢吩地大谷地滐沼村之 竹森村との間に於ける. 地理学，9. (1941). 5 . 拙稿：土地割換制とその固定へ の過程. 地理学研究, 1. 山形大教育学部地理学研究会 (1953). 6. 拙稿 : 米沢盆 地大谷地開拓の歴史地理学的研究，東北地理，6. (1953). 7. 乍恐以畫付御挀訟 申上候事，明和 9 竹田作右衛門氏所蔵，以下引用の文畫も同様（この竹田文䟧は現 在山形大学教育学部に移つている). 8. Yoshimura : Desolved Oxygen of the lake water of Japan. Science Report of the Tokyō-Bunrika Daigaku, Section C, No，8，(1933).9. 三木茂: 深沼ヶ池，特に浮島の生態研究，京都府史蹟名勝天然 記念物調查報告 (1929). 10. James G. Needham and T. J. Lloyd : The life of inland water (1930) p. 353,. 11. Paul S. Welch : Vertical distribution of summer temperatre in the false bottom of certain Michigan bog lakes. Ecology, Tol. 20, No. 1 (1939).

\section{ŌYACHI IN THE YONEZAWA BASIN, YAMAGATA PREFECTURE}

\section{Yoshinobu YOSHIDA*}

Oyachi, situated in the northeastern corner of the Yonezawa Basin (Fig. 1), is a kind of bog lake with an area of 1020 ha, 950 ha of which is used as rice fields and the rest, $70 \mathrm{ha}$, is left as marsh. The rice fields here are classified into the two, the "Yachita" (marshy paddy fields) and the "Ukita" (floating paddy fields), the area is 700 ha. and 250 ha. respectively. The Yachita occupying the marginal part of Oyachi makes the muddy fields of powdered peat filled with water throughout the year. The Ukita which mainly occupies the central part is rather recently reclaimed fields. In Ōyachi there run very many waterways and "Yachibune" (a kind of boat) is used to carry fertilizer or rice plants. When the uncultivated part or a ridge $4 \sim 6 \mathrm{~m}$. wide betwsen rice fields is stamped violently, the ground roundabout shakes. The peat layer can be penetrated with boring stick by one hand, and as soon as it is pierced through, no resistance is felt. When the boring stick is drawn out, brown liquid mud blows out with methane for $5 \sim 7$ seconds, then it rests at the depth of $3 \sim 5 \mathrm{c.m}$. from the surface. The subsidence of the surface of Oyachi took place during 1931 1952 amounted 60 90cm. as shown in Fig. 2 .

Having an idea that Oyachi is a kind of bog lake, the writer made surveys in summer, 1953, at 423 points in Oyachi area on (a) thickness of the peat layer, (b) depth of the water lying beneath the peat, (c) thickness of the mud

* Institute of Geography, Faculty of Education, Yamagata University 
covering the base and (d) depth of the base from the surface of Oyachi. The results are shown in Fig. $3 \sim 8$.

(a) Although thickness of the peat layer (Fig. 3) ranges from $1 \mathrm{~m}$. to $2 \mathrm{~m}$., it is generally thick at the central part and thin at the marginal part of Oyachi. The peat deposits are saturated and underlain by water of low temperature, so that, for example, when the surface temperature of Ukita is $29.8^{\circ} \mathrm{C}$, the temperature at a depth of $50 \mathrm{~cm}$. is only $14.9^{\circ} \mathrm{C}$. Therefore, growth of rice plants is poor, and even alpine plants grow there, though the altitude of the area is only $212 \mathrm{~m}$. above sea-level. (b) Fig. 4 shows the depth from the surface of peat layer to that of the mud, namely the shape of the lake basin. The deepest point is $8 \mathrm{~m}$. in depth, and besides there are three sub-lake basins. The southern half of Oyachi has only a depth between 2 and $4 \mathrm{~m}$. Fig. 5 shows the depth of Lake Hakuryū, which is situated in the deepest basin of the Oyachi bog lake. The maximum depth of water, however, is only $1.9 \mathrm{~m}$. That is to say, the bottom of the lake is a false bottom. (d) Fig. 6 shows the shape of base of the bog lake by contour lines in altitude above sea-level. As the result of borings, six rises and eight hollows were discovered in the base. The lowest (deepest) portion coincides with the area of Lake Hakuryü. Comparing Fig. 6 with Fig. 4, it is observed the location of the deepest zones of the base deviates to the east from those in the lake basin, and unevenness of the former is remarkable. (c) Fig. 7 shows the thickness of the mud deposited on the base and it amounts $8 \mathrm{~m}$. at the deepest part. It proves that the lower the bas lies the more the mud has been deposited. Fig. 8 is the cross section along A-B (see Fig. 1) showing the relation between peat layer, water, mud and hase.

It had been planned to reclaim Oyachi by draining so as to make the area into a land suitable for cultivation, and the Biruzawa Reservoir with a pondage of $2,190,000 \mathrm{~m}^{3}$. has been completed. Now the draining project is just to be carried on. But as the quantity of water in Ōyachi bog lake amounts 20,000, $000 \mathrm{~m}^{3}$., it is necessary to make a draining canal from a point $12 \mathrm{~km}$. distant or to drain the area by electric power. After draining was accomplished, the writer thinks, it is necessary to bring enough soil from other places into the area or to take off the peat deposits from the area. 